\title{
LOSS ASSESSMENT AND THE ESTIMATION OF ECONOMIC INFESTATION LEVELS OF TUTA ABSOLUTA (MEYRICK) IN TOMATO CROPS AT EL- SHARKIA GOVERNORATE
}

\author{
MONA. I. AMMAR; M. H. A. SOLIMAN and AFAF M.S. EL- ROBY
}

Plant Protection Research Institute, (ARC), Dokki, Giza, Egypt.

(Manuscript received 22 May 2018)

\begin{abstract}

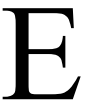
xperiment was carried out for two successive seasons (2016 and 2017) at EL- Sharkia governorate. In both seasons tomato; plant "alsa" variety were cultivated to obtain different levels of infestation by Tuta absoluta of tomato crop were sprayed periodically with King chem $5.7 \%$ WG (Emamectin benzoate). Results showed simple correlation " $r$ " values obtained were strong significantly negative indicating a strong negative relationship between the density of infestation (Tuta absoluta) and the corresponding crop yield of tomato produced. The simultaneous effect of some tomato pests (Tuta absoluta, Bemisia tabaci and Tetranychus urticae) infestation on the crop yield indicated that the three factors were responsible for $73 \%$ and $93 \%$ of variability in the average weight of crop yield in 2016 - 2017 respectively. This study aims to the determination of economic infestation threshold level and economic injury level of Tuta absoluta to be used as a tool for controlling Tuta absoluta under Field conditions. Data indicated that (General Equilibrium Position (G.E.P.)) between 55 to 61 larvae / 20 leaves, Economic Threshold Level (E.T.L)] between 57 to 72 larvae / 20 leaves, [Economic Injury Level ( E.I.L)], 78 to 103 larvae / 20 leaves at this level of infestation control measures must be applied.
\end{abstract}

\section{INTRODUCTION}

Tomato leaf miner (TLM), Tuta absoluta (Meyrick), (Lepidoptera: Gelechiidae), is a key pest at tomato plants and in it native at the western part of South America, invaded Brazil around 1980 (Souza \& Reis, 1992). It is now a devastating pest of tomatos crop in South America, Europe, Africa and Asia (Tropea Garzia et al., 2012; Zappala' et al., 2013). This pest is crossing borders and devastating tomato production in both protected and open fields (EPPO, 2008, 2009; FERA, 2009). In Egypt, $T$. absoluta was spread rapidly and it is currently considered a key insect pest on tomato plants, both in greenhouses and open-fields. Damage is caused by larval tunneling and they can penetrate young stems and fruits which finally result in the loss of over $80 \%$ of fruits (Desneux et al., 2011). During the last decades, TLM were controlled the utilization of chemical insecticides. Environmental safety of the insecticides is the first and foremost criterion for TLM control programs (Tropea Garzia et al., 2012). In most countries where T. absoluta occurs, the main control strategy includes frequent treatments by chemical insecticides, because without control, $T$. absoluta causes about $100 \%$ yield losses and dramatically decreases the fruit quality 
in both field and greenhouse tomato plants (Gilardo'n et al., 2001; Tropea Garzia et al., 2012).

The main objectives of two studies were: Estimation of Economic levels of Infestation and the simultaneous effect of some tomato pest's infestation on the crop yield as well as the approximate damage threshold.

\section{MATERIALS AND METHODS}

\section{Loss assessment and estimation of economic levels of infestation:- \\ Design of the experiment}

This experiment was carried out for two successive seasons (2016 and 2017) at EL- Sharkia governorate. In both seasons tomato plant of variety "alsa" was sown in $15^{\text {th }}$ of May and left until $26^{\text {th }}$ of Augusta in an area of about $\left(2000 \mathrm{~m}^{2}\right)$ divided into fifteen equal rectangular blocks separated from each other by belts of 2 meters wide. Each (treatment) block $\left(133.5 \mathrm{~m}^{2}\right)$ was subdivided into 3 plots $\left(44.5 \mathrm{~m}^{2}\right)$ each plot. The plots were then split into two equal divisions (20 rows each); one used for sampling and the other left untouched until harvesting (for the yield estimation).

To obtain different levels of infestation by Tuta absoluta of tomato plants were sprayed periodically with King chem $5.7 \%$ WG $30 \mathrm{~cm} / 200 \mathrm{~L}$.treatment /Fadden. The insecticidal formulations were applied by means of a compression knapsack sprayer. In both seasons, spraying started on June $25^{\text {th }}$ according to following schedule (Table 1) All the experimental plots received the same normal agricultural practices.

\section{Estimation of infestation by Tuta absoluta (Meyrick):}

Starting on June 23 and until end of August and continued till harvest, weakly samples of 20 leaves were collected at random from each replicate. The samples were kept in paper bags and transferred to the laboratory to examine and count the existed pests.

Table 1. Treatment dates by King chem 5.7\% WG throughout two successive seasons, 2016- 2017at Sharkia Governorate.

\begin{tabular}{|c|c|c|c|c|c|c|c|c|c|c|c|c|c|c|c|}
\hline $\begin{array}{c}\text { No. of } \\
\text { treatment }\end{array}$ & 1 & 2 & 3 & 4 & 5 & 6 & 7 & 8 & 9 & 10 & 11 & 12 & 13 & 14 & 15 \\
\hline $\begin{array}{l}\text { No. of } \\
\text { sprayer }\end{array}$ & & & & & & & & & & & & & & & Control \\
\hline 1 & $25 / 6$ & $25 / 6$ & $25 / 6$ & $25 / 6$ & $25 / 6$ & $25 / 6$ & $25 / 6$ & $25 / 6$ & $25 / 6$ & $25 / 6$ & $25 / 6$ & $25 / 6$ & $25 / 6$ & $25 / 6$ & \\
\hline 2 & & $24 / 7$ & $14 / 7$ & $10 / 7$ & $7 / 7$ & $5 / 7$ & $3 / 7$ & $2 / 7$ & $1 / 7$ & $1 / 7$ & $30 / 6$ & $30 / 6$ & $29 / 6$ & $29 / 6$ & \\
\hline 3 & & & $3 / 8$ & $25 / 7$ & $19 / 7$ & $15 / 7$ & $11 / 7$ & $9 / 7$ & $7 / 7$ & $7 / 7$ & $5 / 7$ & $5 / 7$ & $3 / 7$ & $3 / 7$ & \\
\hline 4 & & & & $9 / 8$ & $31 / 7$ & $25 / 7$ & $19 / 7$ & $16 / 7$ & $14 / 7$ & $14 / 7$ & $10 / 7$ & $10 / 7$ & $7 / 7$ & $7 / 7$ & \\
\hline 5 & & & & & $12 / 8$ & $4 / 8$ & $27 / 7$ & $23 / 7$ & $21 / 7$ & $21 / 7$ & $15 / 7$ & $15 / 7$ & $11 / 7$ & $11 / 7$ & \\
\hline 6 & & & & & & $14 / 8$ & $4 / 8$ & $30 / 7$ & $28 / 7$ & $28 / 7$ & $20 / 7$ & $20 / 7$ & $15 / 7$ & $15 / 7$ & \\
\hline 7 & & & & & & & $12 / 8$ & $6 / 8$ & $4 / 8$ & $4 / 8$ & $25 / 7$ & $25 / 7$ & $19 / 7$ & $19 / 7$ & \\
\hline 8 & & & & & & & & $14 / 8$ & $11 / 8$ & $11 / 8$ & $30 / 7$ & $30 / 7$ & $23 / 7$ & $23 / 7$ & \\
\hline 9 & & & & & & & & & $18 / 8$ & $18 / 8$ & $4 / 8$ & $4 / 8$ & $27 / 7$ & $27 / 7$ & \\
\hline 10 & & & & & & & & & & $24 / 8$ & $9 / 8$ & $9 / 8$ & $31 / 7$ & $31 / 7$ & \\
\hline 11 & & & & & & & & & & & $14 / 8$ & $14 / 8$ & $4 / 8$ & $4 / 8$ & \\
\hline 12 & & & & & & & & & & & & $19 / 8$ & $8 / 8$ & $8 / 8$ & \\
\hline 13 & & & & & & & & & & & & & $12 / 8$ & $12 / 8$ & \\
\hline 14 & & & & & & & & & & & & & & $16 / 8$ & \\
\hline 15 & & & & & & & & & & & & & & & \\
\hline
\end{tabular}


Tomato were harvested; on Augusta 30, for two seasons 2016 - 2017. The weight of produced by 99 tomato plants in each division was recorded, and the average weight of yield for each treatment was calculated.

\section{RESULTS AND DISCUSSION}

\section{Estimation of Economic levels of Infestation:}

\section{A. The infestation-yield relationship:}

In order to estimate the damage in tomatoes yield due to infestation by TLM at different infestation level, the simple correlation formula was applied.

The population density of the pest was represented by the average number of TLM $\mathrm{s}^{1}$ larva as independent variable $(X)$, while tomato yield was represented was represented as dependent variable $(Y)$.

The variations that occurred in the yield crop in tomato owing to the infestation by $T$. absolute were detected through the application of the linear regression formula: $\hat{Y}=a+b X$ "prediction equation" (Goulden 1960), where "Ŷ" is the new estimated yield weights, "X" is the degree of infestation by T. absoluta, "a" is the origin of the linear the value of " $y$ " for " $x "$ = "o" and "b" is the slope of the time. Thus "b" represents the decrease in " $y$ " for a unit increase in " $x$ ".

The linear regression coefficient "b" was helpful in determining the slope of the straight regression liners.

When simple correlation coefficient " $r$ " was significant the regression coefficient "b" was calculated. Also curved nonlinear regression line (Curvilinear Relations) was estimated for T. absoluta and (coefficient of determination $r^{2}$ ) was calculated for $T$. absoluta

Data given in table (2) showed ample sets of infestation that the simple correlation coefficients could be worked out for the relationship between the number of Tuta absoluta ( $\mathrm{x}$ ) on one hand and the yield of tomato crop ( $\mathrm{y}$ ) on the other hand, the simple correlation " $r$ " values obtained were negative highest significantly indicating a strong negative relationship between the density of infestation and the corresponding yield of tomatoes production. 
Table 2. The fluctuation in tomato yield "y" of tomato plant and number of Tuta absoluta during two seasons 2016 - 2017.

\begin{tabular}{|c|c|c|c|c|c|c|}
\hline Year & & & & & 17 & \\
\hline Treatment No. & $\begin{array}{l}\text { number of } \\
\text { Larvae }\end{array}$ & $\begin{array}{c}\text { yield in } \\
\text { kg./ plant }\end{array}$ & $\hat{\mathrm{Y}} 1$ & $\begin{array}{l}\text { number } \\
\text { of Larvae }\end{array}$ & $\begin{array}{l}\text { yield in } \\
\text { kg./ plant }\end{array}$ & $\hat{\mathrm{Y}} 1$ \\
\hline 1 & 50 & 372 & 301.16 & 45 & 390 & 350.20 \\
\hline 2 & 53 & 345 & 294.11 & 49 & 377 & 333.69 \\
\hline 3 & 58 & 285 & 282.36 & 55 & 282 & 308.92 \\
\hline 4 & 60 & 276 & 277.66 & 57 & 280 & 300.67 \\
\hline 5 & 61 & 270 & 275.31 & 63 & 267 & 275.90 \\
\hline 6 & 72 & 231 & 249.45 & 69 & 240 & 251.14 \\
\hline 7 & 78 & 225 & 235.35 & 71 & 228 & 242.88 \\
\hline 8 & 78 & 219 & 235.35 & 73 & 212 & 234.63 \\
\hline 9 & 79 & 210 & 233.00 & 75 & 208 & 226.37 \\
\hline 10 & 82 & 207 & 225.95 & 80 & 205 & 205.73 \\
\hline 11 & 88 & 183 & 211.85 & 82 & 201 & 197.48 \\
\hline 12 & 89 & 177 & 209.50 & 88 & 179 & 172.71 \\
\hline 13 & 92 & 174 & 202.44 & 89 & 171 & 168.58 \\
\hline 14 & 103 & 166 & 176.59 & 94 & 145 & 147.95 \\
\hline 15 & 142 & 155 & 84.92 & 108 & 122 & 90.16 \\
\hline Total & 1185 & 3495 & $\begin{array}{r}2366.6 \\
3\end{array}$ & 1098 & 3507 & $\begin{array}{r}3996.1 \\
6\end{array}$ \\
\hline Mean & 79 & 233 & 233 & 73.2 & 233.8 & 233.80 \\
\hline Correlation (r) & $-0.843 * * *$ & & & $-0.955 * * *$ & & \\
\hline $\begin{array}{l}\text { Regression co } \\
\text { (b) }\end{array}$ & $-2.35 * * *$ & & & $-4.12 * * *$ & & \\
\hline $\begin{array}{c}\text { Coefficient of } \\
\text { determination } \\
" r^{2 "}\end{array}$ & 0.710 & & & 0.912 & & \\
\hline
\end{tabular}

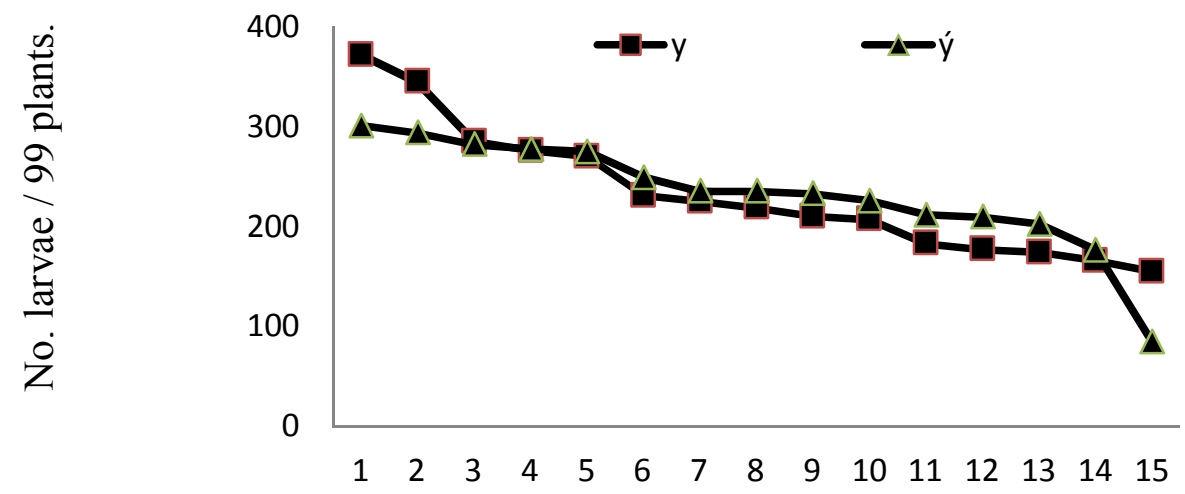

Average tomato yield

Fig. 1. the linear regression relationship between Tuta absoluta infestation levels "x" (expressed as average number of larvae/ 99 plants) and average tomato yield "y" during 2016 season. 


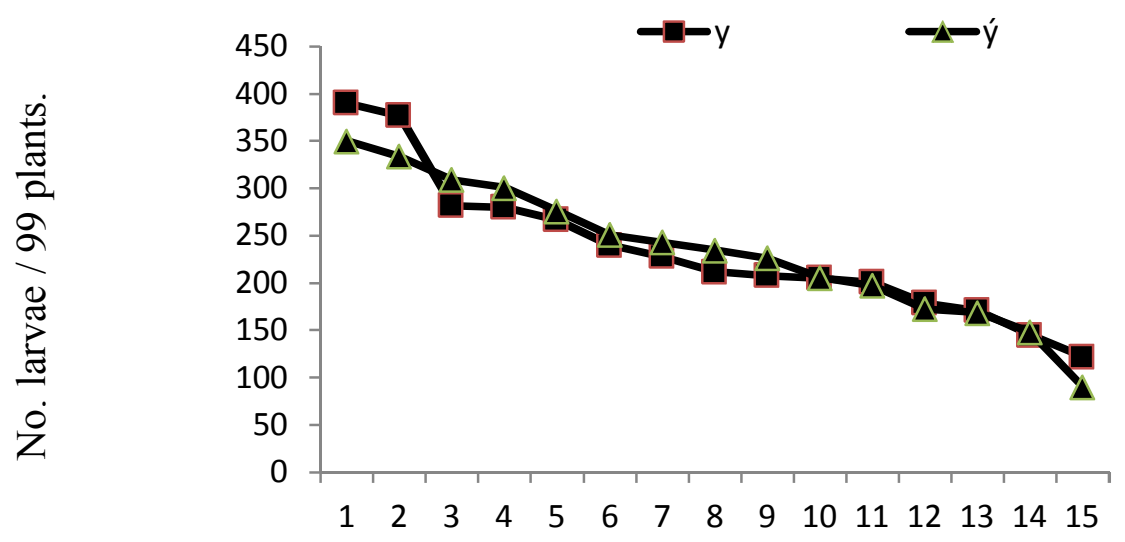

Average tomato yield

Fig. 2. the linear regression relationship between Tuta absoluta infestation levels " $\mathrm{x"}$ (expressed as average number of larvae/ 99 plants) for and average tomato yield "y" during 2017 season.

\section{The simultaneous effect of some tomato pests infestation on the yield}

The C-multipliers method, to determine the spate effect of each of these pests on the yield together with the actual corrected yield, as being affected by each pest. The independent factors $\left(\mathrm{x}_{1}, \mathrm{x}_{2}\right.$ and $\left.\mathrm{x}_{3}\right)$ referred to the number of Tuta absoluta , Bemisia tabaci and Tetranychus urticae and tomato yield averages represented the dependent factor "Y". The values for the dependent and independent variables $\left(b_{1}, b_{2}\right.$ and $b_{3}$ ) are given in Table (3). These values indicated that the three factors were responsible for $73 \%$ and $93 \%$ of variability in the average weight tomato yield in 2016-2017 respectively.

The partial regression values $\left(b_{1}\right)$ for the effect of Tuta absoluta on the yield (when the two other factors $x_{2}$ and $x_{3}$ ) remained constant around their averages) were significant negative for both seasons 2016and2017, respectively. The partial regression values $\left(b_{2}\right)$ for the effect of $B$. tabaci on the yield (when the three other factors $x_{1}$ and $x_{3}$ ) remained constant around their averages) was insignificant and negative for both seasons 2016 and 2017. The partial regression values $\left(b_{3}\right)$ for the effect of $T$. urticae on the yield (when the three other factors $\mathrm{x}_{1}-\mathrm{x}_{2}$ ) remained constant around their averages) were insignificant and negative for both seasons 2016 and 2017, respectively. 
Table 3. Analysis of variance for three tomato pests (Tuta absoluta , Bemisia tabaci and Tetranychus urticae) together sharkia, 2016-2017.

\begin{tabular}{|c|c|c|c|c|c|c|c|c|c|c|c|c|}
\hline Year & \multicolumn{6}{|c|}{2016} & \multicolumn{6}{|c|}{2017} \\
\hline $\begin{array}{c}\text { Variance } \\
\text { data }\end{array}$ & D.F & S.S & M.S & $\mathrm{F}$ & $P$ & $\begin{array}{l}\text { Explained } \\
\text { variance }\end{array}$ & D.F & S.S & M.S & $\mathrm{F}$ & $P$ & $\begin{array}{l}\text { Explained } \\
\text { variance }\end{array}$ \\
\hline Regression & 3 & 42361 & 14120 & \multirow{3}{*}{9.37} & \multirow{3}{*}{0.002} & \multirow{3}{*}{$72 \%$} & 1 & 75302 & 25101 & \multirow{3}{*}{49.19} & \multirow{3}{*}{$<.0001$} & \multirow{3}{*}{$93 \%$} \\
\hline Error & 11 & 16585 & \multirow{2}{*}{1507.72} & & & & 3 & 5612.74 & & & & \\
\hline Total & 14 & 58946 & & & & & 14 & 80914 & & & & \\
\hline
\end{tabular}

\section{The approximate damage threshold:}

The injury caused by Tuta absoluta in tomato during seasonal activity showed that three damage occurred during of vegetative growth and formation of tomato fruit. Statistical analysis showed that population density of these Tuta absoluta was highly significant correlated with main yield. This injure are mainly caused decreasing to the amount of tomatoes yield harvested. Therefore, losses assessment must be depend on yield weight decline. Estimation of "Economic Levels of Infestation" will be based on correlation different levels of population density of Tuta absoluta and tomato weight yield per plant. Was Pedigo et al. (1986) more convenience to illustrate definition of "Economic Levels".

\section{In the first season 2016}

Regarding the part of population density during main period of seasonal activity (26, June to 15, August, 2016 and 2017) estimation of economic levels of infestation showed that, when population density of Tuta absoluta less than 61 larvae / 20 leaves could be regarded as (General Equilibrium Position), when reached population to 72 larvae / 20 leaves, the chi-square $\left(X^{2}\right)$ value for the yield (15.36) and significant drop in the weight yield was happened. Therefore, 72 larvae / 20 leaves could be regarded as [Economic Threshold Level (E.T.L)], no need for control measures, but must be ready if population density increases above that level. Afterwards, population density increased upwards from 72 to 103 larvae / 20 leaves, the yield loss decreased from 231 to166 kgs. /weight the obtain significant $X^{2}$ value (10.22). This level of infestation could be regarded as [Economic Injury Level (E.I.L)], at this level of infestation control measures must be applied. Then, population density increased upwards from 103 to 142 individuals/ samples the yield loss decreased to 155 kgs. / weight yield the obtain $X^{2}$ value (5.21) was significant. This level of infestation could be regarded as [Economic Damage Level (E.D.L)], (Table 4). 


\section{In second season 2017}

Regarding the part of population density during main period of seasonal activity (26, June to 15, August, 2016 and 2017) estimation of economic levels of infestation showed that, when population density of Tuta absoluta less than 55 larvae / 20 leaves could be regarded as (G. E. P.). When population reached to 57 larvae / 20 leaves, the chi-square $\left(X^{2}\right)$ value for the yield was (22.75), highly significant drop in the yield was occurred. Therefore, 57 larvae / 20 leaves could be regarded as (E.T.L), no need for control measures, but must be ready if population density increases above that level. Afterwards, population density increased upwards from 57 to 88 larvae / 20 leaves, the yield loss decreased to 280 to $179 \mathrm{kgs}$. /weight, the obtain $X^{2}$ value (15.56) was significant. This level of infestation could be regarded as (E.I.L), at this level of infestation control measures must be applied. Then, population density increased upwards from 88 to 108 individuals/ sample the yield loss decreased to $122 \mathrm{kgs}$. / weight obtain $\mathrm{X}^{2}$ value (2.04) was insignificant. This level of infestation could be regarded as (E.D.L)]. (Table 5).

\section{CONCLUSION}

This study shows that the determination of economic threshold level and economic injury level could be used as a tool for timely control of Tuta absoluta under Field conditions.

The data indicated that (General Equilibrium Position (G.E.P.)) between 55 to 61 larvae / 20 leaves, Economic Threshold Level (E.T.L)] between 57 to 72 larvae / 20 leaves, [Economic Injury Level ( E.I.L)], 78 to 103 larvae / 20 leaves at this level of infestation control measures must be applied.

Table 4. Economic injury levels and economic damage threshold in tomato plants infested by Tuta absoluta in EL- Sharkia governorate during 2016 and 2017 seasons.

\begin{tabular}{|c|c|c|c|c|}
\hline \multirow[b]{2}{*}{ No. of treatment } & \multicolumn{2}{|l|}{2016} & \multicolumn{2}{|l|}{2017} \\
\hline & Number of larvae & $\begin{array}{c}\text { Weight of } \\
\text { yield }\end{array}$ & Number of larvae & $\begin{array}{c}\text { Weight of } \\
\text { yield }\end{array}$ \\
\hline 1 & 50 & 372 & 45 & 390 \\
\hline 2 & 53 & 345 & 49 & 377 \\
\hline 3 & 58 & 285 & 55 (G. E. P.) & 282 \\
\hline 4 & 60 & 276 & 57 (E.T.L) & 280 \\
\hline 5 & 61 (G. E. P.) & 270 & 63 & 267 \\
\hline 6 & 72 (E.T.L) & 231 & 69 & 240 \\
\hline 7 & 78 & 225 & 71 & 228 \\
\hline 8 & 78 & 219 & 73 & 212 \\
\hline 9 & 79 & 210 & 75 & 208 \\
\hline 10 & 82 & 207 & 80 & 205 \\
\hline 11 & 88 & 183 & 82 & 201 \\
\hline 12 & 89 & 177 & $88 \quad$ (E.I.L) & 179 \\
\hline 13 & 92 & 174 & 89 & 171 \\
\hline 14 & 103 (E.I.L) & 166 & 94 & 145 \\
\hline 15 & 142 (E.D.L) & 155 & 108 (E.D.L) & 122 \\
\hline Total & 1185 & 3495 & 1098 & 3507 \\
\hline
\end{tabular}




\section{REFERENCES}

1. Desneux N, Luna MG, Guillemaud T, Urbaneja A. 2011. The invasive South American tomato pinworm, Tuta absoluta, continues to spread in Afro-Eurasia and beyond: the new threat to tomato world production. J Pest Sci 84:403-8.

2. EPPO. 2008. Additional information provided by Spain on EPPOA1 pest. EPPO reporting service (ESTa/2008-01).

3. EPPO. 2009. First report of Tuta absoluta in France. EPPO reporting service 2009/003.

4. FERA. 2009. The first outbreak of the South American tomato moth Tuta absoluta in the U.K. Available at: http://www.fera.defra.gov.uk.

5. Gilardo'n E;M Pocovi, C Hernade'z, andA Olsen. 2001. Papel dos tricomas glandulares da folha do tomateiro na oviposica o de Tuta absoluta. Pesq Agrop Brasileira 36:585-8.

6. Pedigo, L.P.; S.H. Hutchins and L.G. Higley. 1986. Economic injury levels in theory and practice. Ann. Rev. Entom.; 31: 341-368.

7. SAS Institute. 2004. SAS/STAT. guide for personal computers. Ver. 8.Cary (NC): SAS Institute.

8. Souza JC, and PR Reis. 1992. Trac, a-do-tomateiro, histo' rico, reconhecimento, biologia, prejuı'zos e controle. EPAMIG, Belo Horizonte,Brazil.

9. Tropea Garzia G; G Siscaro, A Biondi, and L Zappala`. 2012. Tuta absoluta, a South American pest of tomato now in the EPPO region: biology, distribution and damage. EPPO Bull 42:205-10.

10. Zappala' L; A Biondi, and A Alma. 2013. Natural enemies of the South American moth, Tuta absoluta, in Europe, North Africa and Middle-East, and their potential use in pest control strategies. J Pest Sci 86:635-47. 


\section{تقيم وتقدير الخساره للمستويات الأقتصادية للأصابه}

\section{Tuta absoluta (Meyrick)}

فى نبات الطماطم فى محافظه الشرقيه

منى أبر اهيم عمار ، محمد حسن عبد الرحمن سليمان ، عفاف محمد صالح الروبى

معهد بحوث وقايه النباتات ،مركز البحوث الزراعيه ،الجيزة ،الدقى

نم اجر اء التجربه خلال موسمين منتالين 2016/ 2017 فى محافظة الثرقيه وفى كلا

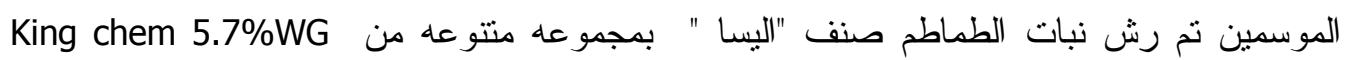
للحصول على مستويلت مختلفه من الأصابه بالتوتا ابسولوتا. وجدت النتائج أن قيم الارتباط البسيط

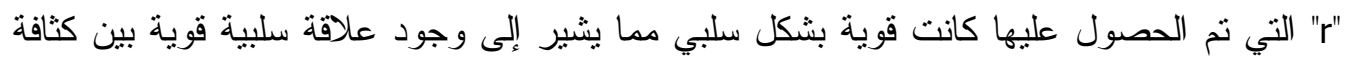

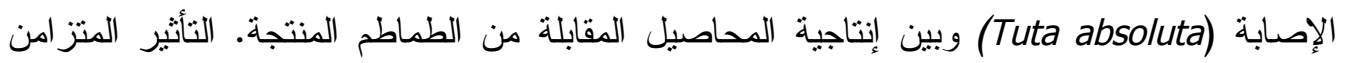

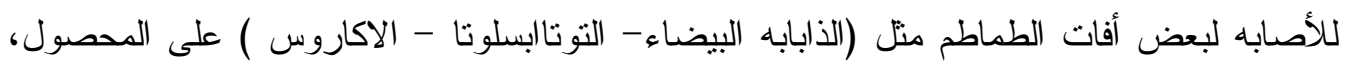
تشير الى ان العوامل الثلاثه مسؤله بنسبه 73\% ، 93\% من التباين فى منوسط الوزن من الته المحصول خلال عام 2016 و 2017 على التوالى.وتبين الدراسة أن تحديد مسنوى البدايه الاقتصادية للسيطرة في الوقت المناسب من Tuta absoluta تحت الظروف الحقليه. أثنارت البيانات

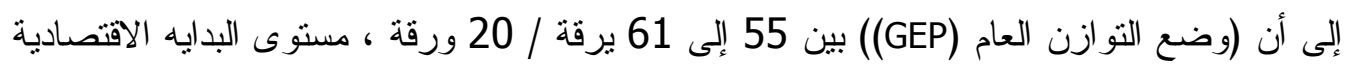
(ETL) يجب نطبيق / 20 ورقة في هذا المسنوى من تدابير مكافحة الإصابة. 
